\title{
Evaluation of $\mathrm{HO}_{\mathrm{x}}$ sources and cycling using measurement-constrained model calculations in a 2-methyl-3-butene-2-ol (MBO) and monoterpene (MT) dominated ecosystem
}

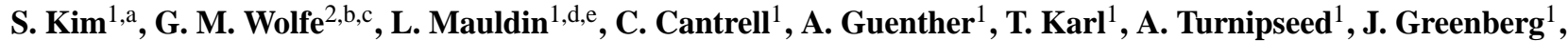 \\ S. R. Hall ${ }^{1}$, K. Ullmann ${ }^{1}$, E. Apel ${ }^{1}$, R. Hornbrook ${ }^{1}$, Y. Kajii ${ }^{3, f}$, Y. Nakashima ${ }^{3, g}$, F. N. Keutsch ${ }^{2}$, J. P. DiGangi ${ }^{2}$, \\ S. B. Henry ${ }^{2}$, L. Kaser ${ }^{4}$, R. Schnitzhofer ${ }^{4}$, M. Graus ${ }^{5,6}$, A. Hansel ${ }^{4}$, W. Zheng ${ }^{1}$, and F. F. Flocke ${ }^{1}$ \\ ${ }^{1}$ ACD/NESL/NCAR Boulder, CO 80301, USA \\ ${ }^{2}$ Department of Chemistry, University of Wisconsin, Madison, WI, USA \\ ${ }^{3}$ Division of Applied Chemistry, Tokyo Metropolitan University, Tokyo \\ ${ }^{4}$ University of Innsbruck, Innsbruck, Austria \\ ${ }^{5}$ CIRES, University of Colorado, Boulder, CO 80309 USA \\ ${ }^{6}$ Chemical Science Division, ESRL-NOAA, Boulder, CO 80305, USA \\ ${ }^{a}$ now at: Department of Earth System Science, University of California, Irvine, CA, USA \\ ${ }^{b}$ now at: Joint Center for Earth Systems Technology, Baltimore County, MD USA \\ ${ }^{c}$ now at: NASA Goddard Space Flight Center, Greenbelt, MD, USA \\ ${ }^{d}$ now at: Department of Physics, University of Helsinki, Helsinki, Finland \\ enow at: Department of Atmospheric and Oceanic Sciences, University of Colorado, Boulder, CO, USA \\ ${ }^{f}$ now at: Graduate School of Environmental Studies and Human and Environmental Studies, Kyoto University, Kyoto, Japan \\ $\mathrm{g}_{\text {now }}$ at: Department of Environmental and Natural Resource Sciences, Tokyo University of Agriculture and Technology, \\ Tokyo, Japan
}

Correspondence to: S. Kim (saewungk@uci.edu)

Received: 8 April 2012 - Published in Atmos. Chem. Phys. Discuss.: 27 June 2012

Revised: 13 December 2012 - Accepted: 7 January 2013 - Published: 21 February 2013

\begin{abstract}
We present a detailed analysis of $\mathrm{OH}$ observations from the BEACHON (Bio-hydro-atmosphere interactions of Energy, Aerosols, Carbon, $\mathrm{H}_{2} \mathrm{O}$, Organics and Nitrogen)ROCS (Rocky Mountain Organic Carbon Study) 2010 field campaign at the Manitou Forest Observatory (MFO), which is a 2-methyl-3-butene-2-ol (MBO) and monoterpene (MT) dominated forest environment. A comprehensive suite of measurements was used to constrain primary production of $\mathrm{OH}$ via ozone photolysis, $\mathrm{OH}$ recycling from $\mathrm{HO}_{2}$, and $\mathrm{OH}$ chemical loss rates, in order to estimate the steady-state concentration of $\mathrm{OH}$. In addition, the University of Washington Chemical Model (UWCM) was used to evaluate the performance of a near-explicit chemical mechanism. The diurnal cycle in $\mathrm{OH}$ from the steady-state calculations is in good agreement with measurement. A comparison between the
\end{abstract}

photolytic production rates and the recycling rates from the $\mathrm{HO}_{2}+\mathrm{NO}$ reaction shows that recycling rates are $\sim 20$ times faster than the photolytic $\mathrm{OH}$ production rates from ozone. Thus, we find that direct measurement of the recycling rates and the $\mathrm{OH}$ loss rates can provide accurate predictions of $\mathrm{OH}$ concentrations. More importantly, we also conclude that a conventional $\mathrm{OH}$ recycling pathway $\left(\mathrm{HO}_{2}+\mathrm{NO}\right)$ can explain the observed $\mathrm{OH}$ levels in this non-isoprene environment. This is in contrast to observations in isoprene-dominated regions, where investigators have observed significant underestimation of $\mathrm{OH}$ and have speculated that unknown sources of $\mathrm{OH}$ are responsible. The highly-constrained UWCM calculation under-predicts observed $\mathrm{HO}_{2}$ by as much as a factor of 8 . As $\mathrm{HO}_{2}$ maintains oxidation capacity by recycling to $\mathrm{OH}$, UWCM underestimates observed $\mathrm{OH}$ by as much as 
a factor of 4 . When the UWCM calculation is constrained by measured $\mathrm{HO}_{2}$, model calculated $\mathrm{OH}$ is in better agreement with the observed $\mathrm{OH}$ levels. Conversely, constraining the model to observed $\mathrm{OH}$ only slightly reduces the model-measurement $\mathrm{HO}_{2}$ discrepancy, implying unknown $\mathrm{HO}_{2}$ sources. These findings demonstrate the importance of constraining the inputs to, and recycling within, the $\mathrm{RO}_{\mathrm{x}}$ radical pool $\left(\mathrm{OH}+\mathrm{HO}_{2}+\mathrm{RO}_{2}\right)$.

\section{Introduction}

Since Levy (1971) first postulated tropospheric OH production, recycling, and loss mechanisms, one of the main research topics in tropospheric photochemistry has been assessing $\mathrm{OH}$ concentrations in the troposphere due to its significance in determining lifetimes of most trace gases including methane, an important greenhouse gas. Concentrations of very reactive (short-lived) species like $\mathrm{OH}$ are usually reasonably well predicted by pseudo-steady state calculations. However, early model results (Levy, 1972; Wofsy et al., 1972; Crutzen, 1974) indicated significant discrepancies for global mean $\mathrm{OH}$ concentrations derived from atmospheric $\mathrm{CH}_{3} \mathrm{CCl}_{3}$ concentrations (Singh, 1977; Lovelock, 1977). Therefore, early modeling studies highlighted the need for development of a comprehensive understanding of ozone-CO- $\mathrm{CH}_{4}-\mathrm{NO}_{\mathrm{x}}\left(\mathrm{NO}+\mathrm{NO}_{2}\right)$ chemistry to resolve these discrepancies (Logan et al., 1981). Although Logan et al. (1981) acknowledged that reactive biogenic volatile organic compounds (BVOCs) such as isoprene and monoterpenes (MT) could significantly depress local concentrations of $\mathrm{OH}$, Chameides and Cicerone (1978) argued that non-methane hydrocarbons (NMHC) could not be a main player for controlling background photochemistry in the troposphere and the stratosphere.

The very reactive nature of $\mathrm{OH}$ has hindered the development of reliable analytical techniques to quantify atmospheric $\mathrm{OH}$ concentrations. In the late 80 s and early 90 s, three different analytical techniques for measuring $\mathrm{OH}-$ long path-differential optical absorption spectrometry (LPDOAS), laser induced fluorescence (LIF), and chemical ionization mass spectrometry (CIMS) - were developed and deployed on multiple platforms to test our understanding of tropospheric photochemistry (Heard and Pilling 2003). $\mathrm{OH}$ measurements by the LIF technique in high isoprene regions have consistently showed significant discrepancies from model predicted $\mathrm{OH}$ (Tan et al., 2001; Lelieveld et al., 2008; Hofzumahaus et al., 2009; and Whalley et al., 2011). Tan et al. (2001) reported $\mathrm{OH}$ and $\mathrm{HO}_{2}$ measurements in a mixed northern hardwood forest (the PROPHET tower laboratory, Pellston, MI USA). This site has a moderate level of NO (100-200 pptv) and high isoprene concentrations (a few ppbv) during the daytime. A highly constrained photochemical box model of $\mathrm{OH}$ significantly underestimated the observed $\mathrm{OH}$ level ( 2.7 times). On the other hand, the model $\mathrm{HO}_{2}$ results agreed well with the observed $\mathrm{HO}_{2}$. This analysis led the authors to conclude that the recycling process from $\mathrm{HO}_{2}$ to $\mathrm{OH}$ is poorly understood. These findings are consistent with recent results in two very different photochemical regimes. Lelieveld et al. (2008) presented airborne $\mathrm{OH}, \mathrm{HO}_{2}$ and other trace gas measurements over the pristine rain forest region of Surinam ( $\mathrm{NO}<50 \mathrm{pptv}$ ). Based on measured precursors, they simulated $\mathrm{OH}$ and $\mathrm{HO}_{2}$ concentrations using a state of the art tropospheric chemistry model. Model results indicated significant underestimation of $\mathrm{OH}$ and reasonable prediction of $\mathrm{HO}_{2}$. The authors hypothesized that unknown peroxy radical recycling processes from reactions of $\mathrm{HO}_{2}$ with isoprene peroxy radicals may be the sources for the excess $\mathrm{OH}$. During the Oxidant and Particle Photochemical Processes (OP-3) field campaign in a Borneo rain forest (another high isoprene-low NO region), investigators reported higher than expected $\mathrm{OH}$ levels that cannot be explained by conventional $\mathrm{OH}$ production and recycling rates (Whalley et al., 2011). Similar findings were also reported in a region with high isoprene concentrations that however is moderately polluted (a few hundreds pptv of NO), the Pearl River Delta area Hofzumahaus et al., 2009; Lu et al., 2012). Generally, it is proposed that unknown recycling processes from $\mathrm{HO}_{2}$ to $\mathrm{OH}$ cause unexplained high levels of $\mathrm{OH}$. Due to much higher concentrations of $\mathrm{HO}_{2}$ in the atmosphere, relatively small recycling rate changes can significantly impact ambient $\mathrm{OH}$ levels. Additional primary radical sources (e.g. from photolysis of oxidized VOC) have also been invoked to explain the "missing OH" in some studies (Stavrakou et al., 2010).

Measured chemical loss rates of $\mathrm{OH}$ have also been employed as a metric to test our understanding of radical-driven photochemistry. Measurements of the chemical $\mathrm{OH}$ loss rate, otherwise known as $\mathrm{OH}$ reactivity (the reciprocal of lifetime of $\mathrm{OH}, \mathrm{s}^{-1}$ ), have been conducted in many different photochemical environments during the past decade. Lou et al. (2010) summarized published $\mathrm{OH}$ reactivity measurement datasets in major photochemical environments (urban, oceanic, and forest environments). The ratios of measured and calculated $\mathrm{OH}$ reactivity vary from $1-3$. A ratio of one indicates that reactive trace gas measurements account for most of the reactive species in the atmosphere. On the other hand, higher ratios can be interpreted as the presence of unknown or unmeasured reactive trace gas species in the atmosphere. Ratios higher than one have mostly been reported in places where BVOCs play a major role in local photochemistry. More recent studies in a Northern European boreal forest reported much higher ratios of measured and calculated $\mathrm{OH}$ reactivity (up to $\sim 10$; Sinha et al., 2010 and Noelscher et al., 2012). To explain the seemingly contradictory findings of missing $\mathrm{OH}$ sinks and sources, it has been suggested that reactions between $\mathrm{OH}$, ozone and BVOCs can produce $\mathrm{OH}$ with significant yields (e.g. Tan et al., 2001 and Lelieveld et al., 2008) 
Table 1. A summary of the instrument suite for BEACHON-ROCS 2010.

\begin{tabular}{|c|c|c|c|}
\hline Measurement Items & Measurement Techniques & $\begin{array}{l}\text { Measurement } \\
\text { Uncertainty }\end{array}$ & References/Manufacturers \\
\hline$J_{\mathrm{NO}_{2}}$ & Filter Radiometer & $6 \%$ & $\begin{array}{l}\text { Metcon INC. } \\
\text { Junkermann et al. (1989) and } \\
\text { Volz-Thomas et al. (1996) }\end{array}$ \\
\hline VOCs and OVOCs & $\begin{array}{l}\text { Proton Transfer Reaction-Time of Flight- } \\
\text { Mass Spectrometry and Proton Transfer } \\
\text { Reaction-Quadrupole-Mass Spectrometry }\end{array}$ & $15 \%$ & $\begin{array}{l}\text { Ionicon Analytik } \\
\text { de Gouw and Warneke (2007) and } \\
\text { Graus et al. (2010) }\end{array}$ \\
\hline PAN and PPN & Chemical Ionization Mass Spectrometry & $20 \%$ & Slusher et al. (2004) \\
\hline VOCs and OVOCs & Total Organic Gas Analyzer (in situ GC) & $15 \%$ & Apel et al. (2002) \\
\hline Glyoxal and Formaldehyde & $\begin{array}{l}\text { Laser Induced Florescence/Laser Induced } \\
\text { Phosphorescence }\end{array}$ & $20 \%$ & $\begin{array}{l}\text { di Gangi et al. (2011), } \\
\text { Hottle et al. (2009) } \\
\text { and Huisman et al. (2008) }\end{array}$ \\
\hline OH Reactivity & Laser Induced Florescence & $5 \%$ & Sadanaga et al. (2004) \\
\hline $\mathrm{OH}$ and $\mathrm{H}_{2} \mathrm{SO}_{4}$ & Chemical Ionization Mass Spectrometry & $35 \%$ & $\begin{array}{l}\text { Tanner et al. (1997) and } \\
\text { Mauldin et al. (2010) }\end{array}$ \\
\hline $\mathrm{HO}_{2}$ and $\mathrm{RO}_{2}$ & Chemical Ionization Mass Spectrometry & $35 \%$ & $\begin{array}{l}\text { Edwards et al. (2003) and } \\
\text { Hornbrook et al. (2011) }\end{array}$ \\
\hline$* \mathrm{CO}$ & Spectroscopic (IR) & $15 \%$ & Thermo Scientific Model 48i \\
\hline $\mathrm{NO} / \mathrm{NO}_{2}$ & Spectroscopic (Flourescence) & $15 \%$ & Eco Physics CLD 88 p \\
\hline $\mathrm{O}_{3}$ & Spectroscopic (U.V.) & $2 \%$ & 2B Technology \\
\hline
\end{tabular}

* The background drift was checked with CO-scrubbed air in every $10 \mathrm{~min}$.

This paper presents comprehensive measurements to constrain $\mathrm{HO}_{2}$ to $\mathrm{OH}$ recycling rates during the BEACHONROCS field campaign (August 2010). The main objective of the BEACHON-ROCS field campaign was to obtain comprehensive atmospheric measurements to constrain the $\mathrm{OH}$ sink, source and recycling terms in a ponderosa pine forest in the Colorado Rocky Mountains. The comprehensive measurement suite was used to constrain steady-state calculations and box model calculations using the Master Chemical Mechanism (Jenkin et al., 1997; Saunders et al., 2003). We systematically compare the modeling results with observations to improve the current understanding of radical photochemistry driven by BVOC oxidation.

\section{Methods}

\subsection{Sampling site description}

The Manitou Forest Observatory (MFO) in the U.S. Forest Service Manitou Experimental Forest near Woodland Park, Colorado U.S.A. (latitude $39^{\circ} 6^{\prime} 0^{\prime \prime}$ longitude $105^{\circ} 5^{\prime} 30^{\prime \prime}$ and elevation $2286 \mathrm{~m}$ ) is situated in a ponderosa pine woodland in the Southern Colorado Rocky Mountain Front Range. The MFO is dominated by ponderosa pine trees that primarily emit 2-methyl-3-butene-2-ol (MBO) and monoterpenes (MT); isoprene and its oxidation products have been detected at relatively low concentrations since the inter-annual observations were initiated in 2009 (Kim et al., 2010). Therefore, uncertainties in isoprene- $\mathrm{OH}$ reaction mechanisms are con- sidered relatively unimportant at this site (Archibald et al., 2010). The open pine woodland at the site has a Leaf Area Index (LAI) of about $3 \mathrm{~m}^{2} \mathrm{~m}^{-2}$ for tree covered surfaces and a tree cover of about $60 \%$ resulting in a landscape average LAI of about $1.9 \mathrm{~m}^{2} \mathrm{~m}^{-2}$. The average tree canopy height is $\sim 18$ $\mathrm{m}$. Major metropolitan areas near the MFO include Denver $(\sim 85 \mathrm{~km})$ and Colorado Springs $(\sim 35 \mathrm{~km})$ in the north eastern direction from the site, the origins of occasional pollution events at the research site. The dominant wind direction was either southwesterly ( $\sim 60 \%)$ or northeasterly $(\sim 40 \%)$ (DiGangi et al., 2012). During the field observation, typical daytime high temperature was observed between 20 to 25 degree $\mathrm{C}$ and 5 to 10 degree $\mathrm{C}$ was observed for daytime low temperature. We did not include any data observed during the precipitation events.

Most atmospheric chemistry measurements at the site were conducted near the flux tower $(\sim 30$ meter height). An overview of the BEACHON-ROCS field campaign measurements is summarized in Table 1. In this paper, we only present the observational data under the canopy $(1.6 \mathrm{~m}$ from the ground). Most of instrumentation listed in Table 1 shared a common inlet except, $\mathrm{CO}, \mathrm{OH}, \mathrm{HO}_{2}, \mathrm{RO}_{2}$, and $\mathrm{OH}$ reactivity that were measured at about the same height within a $20 \mathrm{~m}$ radius from the common inlet. The $J_{\mathrm{NO}_{2}}$ sensor was located on top of the $\mathrm{OH}$ inlet. More detailed experimental configurations will be presented in the BEACHON-ROCS overview paper (Karl et al., 2013). 


\section{2 $\mathrm{OH}, \mathrm{HO}_{2}$, and $\mathrm{RO}_{2}$ measurements by Chemical Ionization Mass Spectrometry}

$\mathrm{OH}$ was measured by chemical ionization mass spectrometry (CIMS) during the BEACHON-ROCS field campaign. The technique was developed by Eisele and Tanner (1991) and they have comprehensively discussed potential interferences and limitations of their initial design. In response to these limitations, Tanner et al. (1997) presented a modified instrument configuration to measure $\mathrm{OH}$ and $\mathrm{H}_{2} \mathrm{SO}_{4}$ as well as a calibration method, which is identical to the instrumentation for this study. This CIMS method uses $\mathrm{NO}_{3}^{-}$for the reagent ion to selectively ionize sulfuric acid in an atmospheric pressure reaction chamber;

$\mathrm{NO}_{3}^{-} \mathrm{HNO}_{3}\left(\mathrm{H}_{2} \mathrm{O}\right)_{n}+\mathrm{H}_{2} \mathrm{SO}_{4} \rightarrow$

$\mathrm{HSO}_{4}^{-}\left(\mathrm{HNO}_{3}\right)_{\mathrm{m}} \mathrm{H}_{2} \mathrm{O}_{\mathrm{p}}+\mathrm{HNO}_{3}+\left(\mathrm{H}_{2} \mathrm{O}\right)_{\mathrm{r}}$

where $m=0$ or $1, n, p$, and $r$ are dependent upon water vapor concentrations

Before the ions are introduced into a detection chamber that consists of an octopole ion beam focus, quadrupole mass filter, and channeltron units, the ion clusters are dissociated in the collisional dissociation chamber (CDC) so that $\mathrm{NO}_{3}^{-}$ and $\mathrm{HSO}_{4}^{-}$are the only ions to be quantified for monitoring ambient concentrations of $\mathrm{H}_{2} \mathrm{SO}_{4}$.

For $\mathrm{OH}$ measurement, ambient $\mathrm{OH}$ is chemically converted into $\mathrm{H}_{2}^{34} \mathrm{SO}_{4}$ before sample air is introduced into the ionization flow tube;

$$
\begin{aligned}
& \mathrm{OH}+{ }^{34} \mathrm{SO}_{2}+\mathrm{M} \rightarrow \mathrm{H}^{34} \mathrm{SO}_{3}+\mathrm{M} \\
& \mathrm{H}^{34} \mathrm{SO}_{3}+\mathrm{O}_{2} \rightarrow{ }^{34} \mathrm{SO}_{3}+\mathrm{HO}_{2} \\
& { }^{34} \mathrm{SO}_{3}+\mathrm{H}_{2} \mathrm{O}+\mathrm{M} \rightarrow \mathrm{H}_{2}^{34} \mathrm{SO}_{4}+\mathrm{M}
\end{aligned}
$$

By applying isotopically-labeled sulfur dioxide, we can separate ambient sulfuric acid from sulfuric acid produced by reaction with $\mathrm{OH}$. Injections of ${ }^{34} \mathrm{SO}_{2}$ and propane, an $\mathrm{OH}$ scrubber for the background signal check, are controlled by two sets of front and rear injectors controlled by a VALCO (Houston, TX, USA) valve unit. The valve cycling period is typically set to 30 seconds.

Ambient $\mathrm{OH}$ and $\mathrm{H}_{2} \mathrm{SO}_{4}$ sensitivity to the CIMS system was calibrated using the scheme presented in Petaja et al. (2009). OH was generated by illuminating the sample air stream with a Hg-pen ray lamp immediately before the CIMS sampling tube ( $1 / 2^{\prime \prime}$ stainless steel tubing). The photons from the lamp were filtered so that only $184.9 \mathrm{~nm}$ photons hit the water vapor in the sample air stream. The amount of photons from the UV lamp intensity was measured using a photomultiplier (R 5764, Hamamatsu Photonics K. K.). With the measured number of photons, the water vapor number density and the absorption cross-section at the given wavelength, $\mathrm{OH}$ concentrations from the photolysis were estimated. More detailed descriptions on the calibration procedure can be found in Petaja et al. (2009) and Sjostedt (2006). The estimated un-

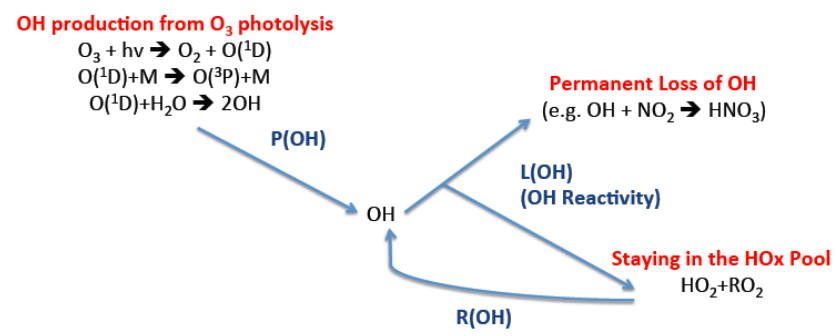

Fig. 1. Steady-state calculation scheme used in this study.

certainty for the $\mathrm{OH}$ measurement is $35 \%$ and the lower limit of detection $\sim 4 \times 10^{5}$ molecules $\mathrm{cm}^{-3}$ for a 5 -min average.

For $\mathrm{HO}_{2}$ and $\mathrm{RO}_{2}$ observations, the same ion chemistry as for $\mathrm{OH}$ quantification is applied. $\mathrm{HO}_{2}$ and $\mathrm{RO}_{2}$ are converted into $\mathrm{OH}$ by applying excess amounts of $\mathrm{NO}(0.3 \%$ in volume) in the upstream of the sample flow. Since another research article on $\mathrm{HO}_{2}$ and $\mathrm{RO}_{2}$ observation and modeling results will be followed, in this paper we briefly introduce the principles of the $\mathrm{HO}_{2}$ and $\mathrm{RO}_{2}$ measurement technique, deployed for BEACHON campaign. Thorough descriptions on potential interferences and analytical characteristics can be found in Edwards et al. (2003) and Hornbrook et al. (2011). In addition, Mauldin et al. (2012) described potential interferences on background signals in $\mathrm{OH}$ quantifications using CIMS but we conducted frequent background characterization (every minute) to adequately subtract background signals.

\subsection{Model calculations}

\subsubsection{Steady-state model}

Highly constrained steady-state $\mathrm{OH}$ concentrations $\left([\mathrm{OH}]_{\mathrm{SS}}\right)$ were estimated based on the radical reaction scheme shown in Fig. 1. We conducted comprehensive measurements to constrain 1) $\mathrm{OH}$ production from ozone photolysis (ozone, $\mathrm{H}_{2} \mathrm{O}$ concentrations and ozone photolysis rate $\left(J_{O_{3}}\right)$ from $\mathrm{NO}_{2}$ photolysis rate $\left(\mathrm{NO}_{2}\right)$ measurements) 2) $\mathrm{OH}$ chemical loss ( $\mathrm{OH}$ reactivity measurement), and 3$) \mathrm{OH}$ recycling from $\mathrm{HO}_{2}\left(\mathrm{HO}_{2}\right.$ and $\mathrm{NO}$ measurements) as summarized in Table 1. The steady-state equation can be defined as follows;

$d[\mathrm{OH}] / d t=\mathrm{P}(\mathrm{OH})+\mathrm{R}(\mathrm{OH})-\mathrm{L}(\mathrm{OH})[\mathrm{OH}]_{\mathrm{SS}}=0$

where,

$P(\mathrm{OH})=2 J_{\mathrm{O}_{3}} k_{7}\left[\mathrm{H}_{2} \mathrm{O}\right]\left[\mathrm{O}_{3}\right] /\left(k_{6}[M]\right)\left(\right.$ molecules $\left.\mathrm{cm}^{-3} \mathrm{~s}^{-1}\right)$

From reactions

$\mathrm{O}_{3}+h v \rightarrow \mathrm{O}_{2}+\mathrm{O}\left({ }^{1} \mathrm{D}\right), J_{\mathrm{O}_{3}}$

$\mathrm{O}\left({ }^{1} \mathrm{D}\right)+\mathrm{M} \rightarrow \mathrm{O}\left({ }^{3} \mathrm{P}\right)+\mathrm{M}, k_{6}$

$\mathrm{O}\left({ }^{1} \mathrm{D}\right)+\mathrm{H}_{2} \mathrm{O} \rightarrow 2 \mathrm{OH}, k_{7}$ 
a)

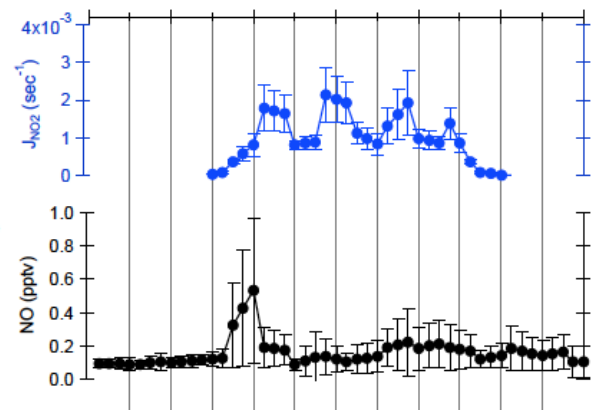

c)

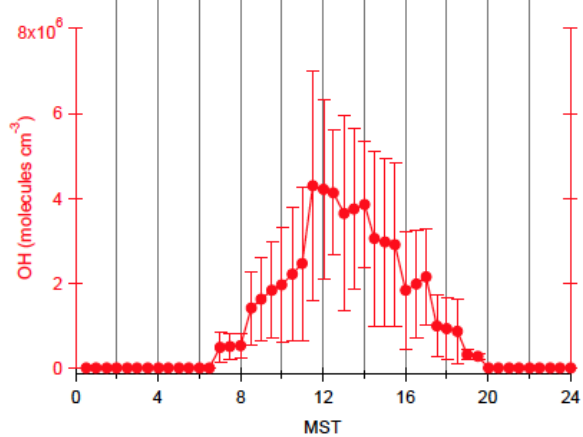

d)

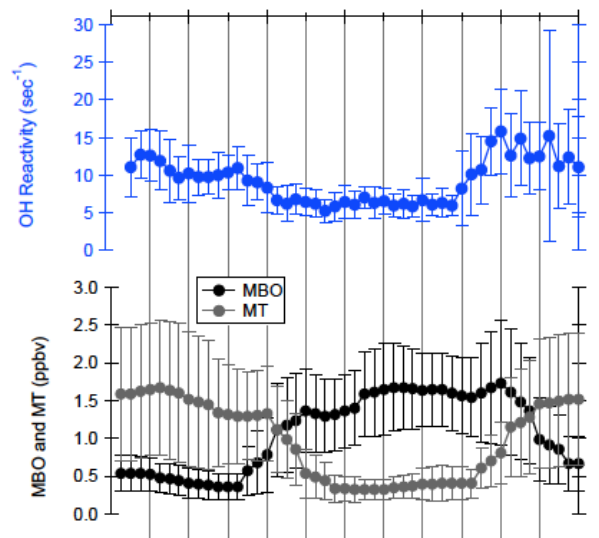

f)

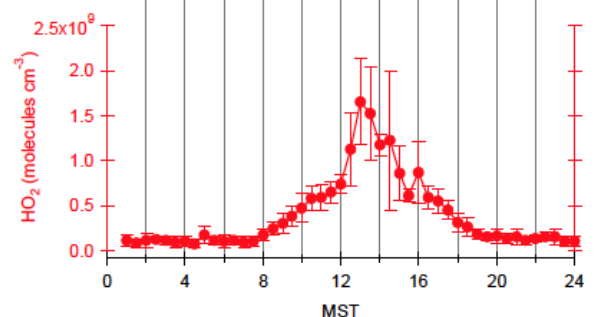

Fig. 2. Averaged diurnal cycles of (a) $J_{\mathrm{NO}_{2}}$, (b) $\mathrm{NO}$, (c) $\mathrm{OH}$, (d) $\mathrm{OH}$ reactivity and (e) $\mathrm{MBO}$ and $\mathrm{MT}$ (f) $\mathrm{HO}_{2}$ during the BEACHON-ROCS field campaign in August 2010.

$\mathrm{L}(\mathrm{OH})=\mathrm{OH}$ reactivity $\left(\mathrm{s}^{-1}\right)$.

$\mathrm{R}(\mathrm{OH})=\mathrm{OH}$ recycling rates (molecules $\mathrm{cm}^{-3} \mathrm{~s}^{-1}$ ).

$J_{\mathrm{O}_{3}}$ was estimated from $J \mathrm{NO}_{2}$ measurements by applying scaling factors from comparisons with theoretically calculated values using the scheme described by Saunders et al. (2003). As previously discussed, the underestimated recycling rates of $\mathrm{OH}$ from $\mathrm{HO}_{2}$ and $\mathrm{RO}_{2}$ have been proposed to be the major reason for unexpected high $\mathrm{OH}$ levels in isoprene rich regions. In this study, we consider only the conventional $\mathrm{OH}$ recycling pathway, which is the reaction of $\mathrm{HO}_{2}$ with NO. Therefore, by comparing $[\mathrm{OH}]_{\mathrm{SS}}$ with measured $\mathrm{OH}$ concentrations $\left([\mathrm{OH}]_{\text {MEA }}\right)$, we can assess whether additional recycling processes are needed to explain the measured levels of $\mathrm{OH}$ in a $\mathrm{MBO}$ and $\mathrm{MT}$ rich region. The uncertainty of $[\mathrm{OH}]_{\mathrm{SS}}$ assessed from the uncertainties of the input parameters is estimated $\sim 45 \%$.

\subsubsection{0-D box model}

Observationally-constrained chemical box model calculations were conducted using the University of Washington Chemical Box Model (UWCM). UWCM incorporates the Leeds Master Chemical Mechanism (MCM) v3.2 (Jenkin et al., 1997; Saunders et al., 2003) into a MATLABbased source code (Wolfe and Thornton, 2011). The model was constrained with 60 -min averaged observations. Utilized meteorological observations include temperature, pressure and relative humidity. $\mathrm{NO}_{2}$ photolysis frequencies measured adjacent to the $\mathrm{OH}$ inlet were used to correct MCM-calculated photolysis frequencies for cloud and canopy cover. Chemical observations include $\mathrm{OH}, \mathrm{HO}_{2}$, $\mathrm{CO}, \mathrm{O}_{3}, \mathrm{NO}, \mathrm{NO}_{2}, \mathrm{MBO}$, isoprene, monoterpenes $(\alpha$ pinene, $\beta$-pinene, limonene, camphene and unspeciated monoterpenes), butadiene, benzene, toluene, oxygenated VOC (formaldehyde, glyoxal, acetone, methanol, acetaldehyde, methyl vinyl ketone, methacrolein, propanal, butanal), PAN and PPN. BEACHON included VOC observations from four different instruments measuring at varying heights with different reporting intervals (Kaser et al., 2012). For the present study, we utilize observations made by the Innsbruck PTR-TOF and the NCAR TOGA instruments at $23 \mathrm{~m}$. To account for vertical gradients in emitted species, MBO and MT observations are scaled from $23 \mathrm{~m}$ to $4 \mathrm{~m}$ using VOC gradient measurements from the NCAR PTR-Quadrupole instrument. Data were averaged to a 60-min diurnal cycle for 17-20 August, except for $\mathrm{NO}_{2}$ and TOGA observations. Insufficient coverage for these species required averaging over the entire dataset (1-31 August). Sensitivity tests were conducted to ensure that data averaging procedures do not affect our conclusions. $\mathrm{CH}_{4}$ and $\mathrm{H}_{2}$ concentrations were held constant at 1770 and $550 \mathrm{ppbv}$, respectively.

Several reactions in MCM v3.2 were updated as described in Wolfe and Thornton (2011). For monoterpenes, the explicit MCM mechanisms were used for $\alpha$-pinene, $\beta$-pinene and limonene and the reaction scheme of Wolfe and Thornton (2011) was used for camphene. Unspeciated monoterpenes were treated similar to the unspeciated sesquiterpenes described in Wolfe and Thornton (2011) but with rate constants taken from the $\beta$-pinene mechanism. Sensitivity tests 
indicate that newly-proposed isoprene peroxy radical isomerization chemistry (Crounse et al., 2011; Peeters and Müller, 2010; Peeters et al., 2009; Wolfe et al., 2012) influences modeled $\mathrm{HO}_{\mathrm{x}}$ concentrations by less than $10 \%$ for the conditions of this study. Given the comprehensive suite of constraints, emission and deposition were not considered explicitly, but an additional lifetime of 24 hours was given to all species to avoid the buildup of long-lived products.

The model was initialized at midnight and integrated for two days. Constraints were updated with observations every $60 \mathrm{~min}$. The first day was treated as a "spin-up" day to allow secondary products to accumulate, and results are shown here for the second day. This model setup was sufficient to reproduce observed daytime $\mathrm{OH}$ reactivity to within $20 \%$, though we caution that a significant fraction of the modeled $\mathrm{OH}$ reactivity $(\sim 40 \%)$ is ascribed to unmeasured oxidized VOC. Results are shown for three scenarios: a base case where $\mathrm{OH}$ and $\mathrm{HO}_{2}$ were not constrained to observations, and two scenarios where either $\mathrm{OH}$ or $\mathrm{HO}_{2}$ were constrained.

\section{Results and discussion}

\subsection{Observed parameters}

The diurnal cycles of $\mathrm{OH}, \mathrm{HO}_{2}, \mathrm{NO}, J_{\mathrm{NO}_{2}}$, BVOC concentrations (MBO and $\mathrm{MT}$ ) and $\mathrm{OH}$ reactivity during the BEACHON-ROCS field campaign are shown in Fig. 2. The $\mathrm{OH}$ and $\mathrm{HO}_{2}$ CIMS inlets (about $3 \mathrm{~m}$ above the ground) were located under the tree canopy. $J_{O_{3}}$ was calculated from $J_{\mathrm{NO}_{2}}$, for which the sensor was located right above the $\mathrm{HO}_{\mathrm{x}}$ inlets, and Fig. 2 shows that sporadic shade resulted in intermittent low, local primary production rates of $\mathrm{OH}$. These low primary $\mathrm{OH}$ production rates are not reflected in the observed $\mathrm{OH}$ and $\mathrm{HO}_{2}$ diurnal cycles, which show a regular diurnal cycle with daytime highs around 12:00 to 14:00. The observations remind us that radical concentrations are not solely governed by solar radiation at the exact location of the measurement instrumentation.

However, the importance of solar radiation for initiating radical chemistry is demonstrated by observations that $\mathrm{OH}$ was below the detection limit $\left(5 \times 10^{5}\right.$ molecules $\left.\mathrm{cm}^{-3}\right)$ in the nighttime. The very low nighttime $\mathrm{OH}$ concentrations are contrary to previous reports of high nighttime $\mathrm{OH}$ levels at a mixed northern hardwood forest (University of Michigan Biological Station, Pellston, MI, USA) by Tan et al. (2001). The study reported that nighttime $\mathrm{OH}$ levels were $\sim 50 \%$ of daytime maximum $\mathrm{OH}$ levels and speculated that Criegee radicals from the ozonolysis of MT could generate nighttime $\mathrm{OH}$. Considering fairly high concentrations of MT $(\sim 1.2 \mathrm{ppbv})$ at MFO during the night, the nighttime observations during BEACHON-ROCS appear to contradict these previous findings, though it is possible that the mechanism for nocturnal $\mathrm{OH}$ generation is highly dependent on the VOC mixture at a particular location. However, in a South Eastern Asian rain forest, the observed nighttime $\mathrm{OH}$ levels were also substantially lower $(\sim 10 \%$ or less than daytime peak OH levels; Whalley et al., 2011) than in the study of Tan et al. (2001).

The observed daytime $\mathrm{OH}$ concentrations during BEACHON-ROCS are similar to previously reported levels in rural forest environments $\left(\sim 4 \times 10^{6}\right.$ molecules $\mathrm{cm}^{-3}$, Tan et al., 2001 and Carslaw et al., 2001). On the other hand, the observed daytime $\mathrm{HO}_{2}$ level during this study is significantly higher ( $\sim$ twice) than the $\mathrm{HO}_{2}$ level observed during these studies. The variability of $\mathrm{HO}_{2}$ concentrations in various environments has not been discussed as much as the variability of $\mathrm{OH}$. This may be because in most cases, measured $\mathrm{HO}_{2}$ showed much better agreement with model estimates than does $\mathrm{OH}$ (e.g. Tan et al., 2001). Any variability of $\mathrm{HO}_{2}$ needs to be examined to assess the recycling source of $\mathrm{OH}$ from $\mathrm{HO}_{2}$. $\mathrm{NO}$, an important reducing agent for $\mathrm{HO}_{2}$, was detected at slightly higher than 100 pptv during the daytime, which is higher than the nominal detection limit of $\sim 60 \mathrm{pptv}$. NO concentrations are much higher than those observed in the remote environments, where the higher than expected OH levels were observed (Lelieveld et al., 2008; Whalley et al., 2011). However, even at such moderate NO levels, models have been shown to under-predict observed $\mathrm{OH}$ concentrations by factors of 2-4 in high-isoprene conditions (Pearl River Delta, China and Pellston, Michigan; Lu et al., 2012).

The average measured $\mathrm{OH}$ reactivity (Fig. 2) is $\sim 6 \mathrm{sec}^{-1}$ during the day and $\sim 10 \mathrm{sec}^{-1}$ at night. Reactive gas measurements indicate that BVOCs, mostly MT $(\sim 0.5 \mathrm{ppbv}$ during daytime and $\sim 1.2 \mathrm{ppbv}$ during nighttime) and MBO $(\sim 1.6 \mathrm{ppbv}$ during daytime and $\sim 0.6 \mathrm{ppbv}$ an average for 10 a.m. to 2 p.m. and 9 p.m. to midnight, respectively), are the dominant $\mathrm{OH}$ sinks inside the forest canopy. The most dominant MT species, observed during the field campaign was $\beta$-pinene $(35.2 \%)$ followed by 3 -carene $(23.0 \%), \alpha$ pinene $(20.9 \%)$ and limonene $(17.5 \%)$. More thorough discussion on VOC observations during the BEACHON-ROCS campaign will be submitted in the same ACP special issue (Kaiser et al., 2013). Contributions of isoprene to $\mathrm{OH}$ reactivity were minor. Isoprene concentrations at the site were relatively low during the BEACHON-ROCS campaign as previously reported (e.g. 0.3 ppbv maximum, $0.1 \mathrm{ppbv}$ on average; Kim et al., 2010). The observed $\mathrm{OH}$ reactivity is comparable to previous measurements in the rural US but significantly lower than values observed in megacities and tropical rain forests (Lou et al., 2010). The observed daytime OH reactivity level during the BEACHON-ROCS campaign was the similar level to that observed in a Northern European boreal environment without any significant environmental perturbation where MT is the most dominant OH sink (Sinha et al., 2010; Noelscher et al., 2012). A more detailed analysis of $\mathrm{OH}$ reactivity and comparison with observed BVOCs at this site will be described in a separate publication (Nakashima et al., 2013). 


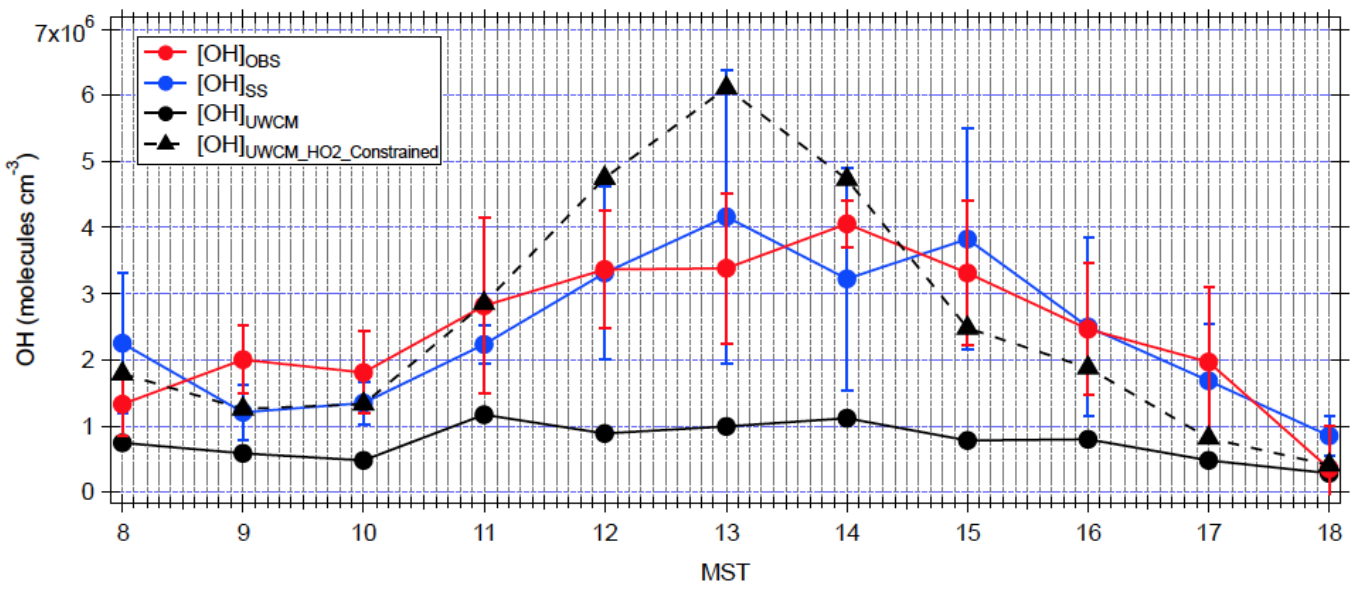

Fig. 3. Averaged diurnal cycles of observed $\mathrm{OH}\left([\mathrm{OH}]_{\mathrm{MEA}}\right)$, steady-state model calculated $\left([\mathrm{OH}]_{\mathrm{SS}}\right)$, UWCM model calculated $\mathrm{OH}$ $\left([\mathrm{OH}]_{\mathrm{UWCM}}\right)$, and $\mathrm{HO}_{2}$ constrained UWCM model calculated $\mathrm{OH}\left([\mathrm{OH}]_{\mathrm{UWCM}_{-} \mathrm{HO}_{2}{ }_{2} \text { Constrained }}\right)$ for 16 to 19 August 2010.

\subsection{Steady-state model calculations}

A four-day period during the study provided a comprehensive dataset including all required measurements for the steady-state calculation (16 to 19 August). Similar diurnal cycles in all input parameters were observed over the fourday period. The averaged daily variations of $[\mathrm{OH}]_{\text {MEA }}$ and $[\mathrm{OH}]_{S S}$ for those four days are shown in Fig. 3. The error bars indicate one standard deviation for the averaged values. The $[\mathrm{OH}]_{S S}$ shown in Fig. 3 captures both the magnitude and daily variation of $[\mathrm{OH}]_{\text {MEA }}$ very well. The disagreement for the early morning is likely due to photolysis of HONO, which was not constrained in the steady-state calculation. High NO concentrations in the early morning have been observed for previous field studies in forested environments and may be explained by soil $\mathrm{NO}_{\mathrm{x}}$ emissions and the boundary layer evolution, although local pollution sources are also a possibility (e.g. Alaghmand et al., 2011). The 1:1 plot between $[\mathrm{OH}]_{\mathrm{MEA}}$ and $[\mathrm{OH}]_{\mathrm{SS}}$ for the four comparison days (10 min average data) is presented in Fig. 4. Although the linear regression analysis has a slope that agrees with the 1:1 line within the uncertainties of measurement and calculations, a high degree of scatter is noticeable which may be explained by significant uncertainties from measurements used for $[\mathrm{OH}]_{\mathrm{SS}}(\sim 50 \%)$ as indicated by error bars obtained from the regression.

The excellent agreement of $[\mathrm{OH}]_{\mathrm{MEA}}$ and $[\mathrm{OH}]_{\mathrm{SS}}$ during this study is contrary to the previous studies in isoprene rich environments. These studies have consistently reported high unexplained levels of $\mathrm{OH}$. To explore this issue further, the averaged daily variations of $\mathrm{OH}$ production rates from ozone photolysis and $\mathrm{OH}$ recycling from the $\mathrm{HO}_{2}$ reaction with $\mathrm{NO}$ are presented in Fig. 5. In addition, the diurnal cycle in the ratio of $\mathrm{OH}$ production rate from $\mathrm{HO}_{2}$ recycling to the $\mathrm{OH}$ production rate from ozone photolysis is also shown. The photolysis production rates observed during

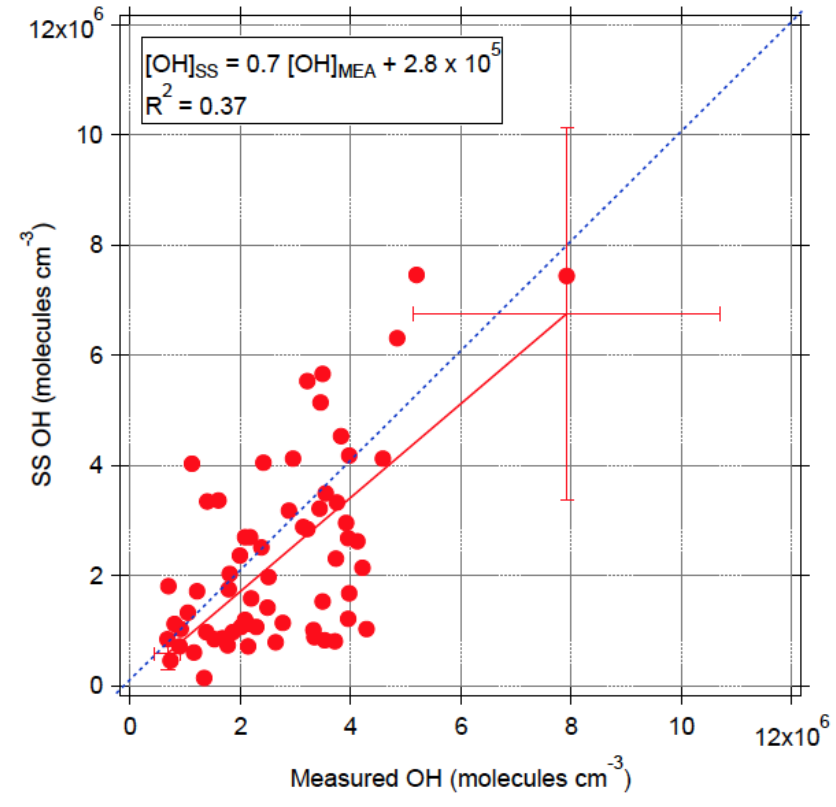

Fig. 4. A correlation plot with $[\mathrm{OH}]_{\mathrm{MEA}}$ and $[\mathrm{OH}]_{\mathrm{SS}}$ (red circles) and a 1:1 line (dashed line). The error bars on the regression line (red) represent uncertainties of $[\mathrm{OH}]_{\mathrm{MEA}}$ and $[\mathrm{OH}]_{\mathrm{SS}}$.

the BEACHON-ROCS campaign are about $30 \%$ of the production rates observed during the PROPHET-1998 campaign (Tan et al., 2001), where the $\mathrm{OH}$ sensor was located above the forest canopy without shading from branches. Considering the attenuated $J_{\mathrm{O}_{3}}$ due to shade and cloud events during this study (Fig. 2), this difference is not surprising. As previously discussed, higher $\mathrm{HO}_{2}$ levels ( $\sim 4$ times) in this study resulted in significantly higher $\mathrm{OH}$ production rates from recycling ( $\sim 4$ times) than those observed at PROPHET-1999 under similar $\mathrm{NO}_{\mathrm{x}}$ conditions $\left(\sim 5 \times 10^{6}\right.$ molecules $\mathrm{cm}^{-3} \mathrm{~s}^{-1}$ vs. $\sim 2 \times 10^{7}$ molecules $\mathrm{cm}^{-3} \mathrm{~s}^{-1}$ ). Therefore, we can neglect 


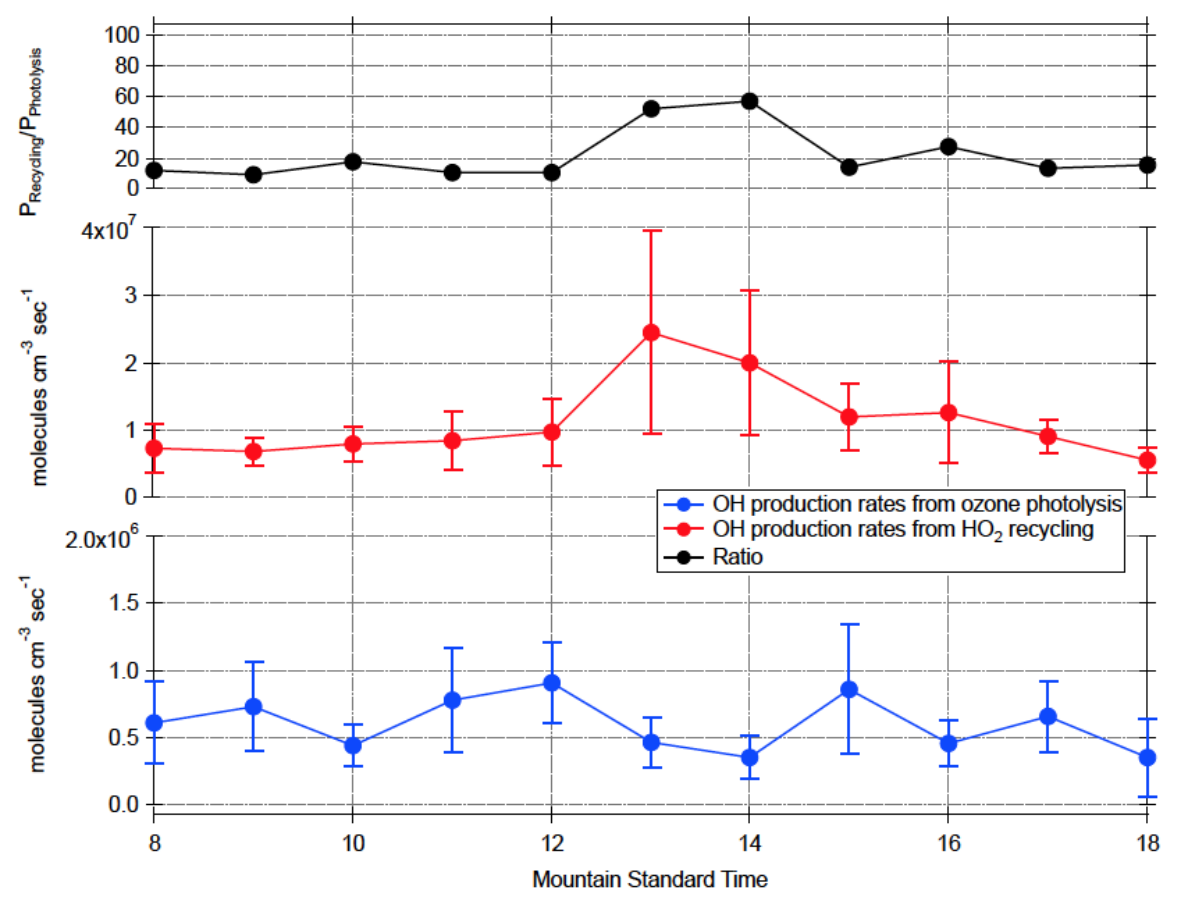

Fig. 5. Averaged diurnal cycles of $\mathrm{OH}$ photolysis production rates (blue), $\mathrm{OH}$ recycling rates $\left(\mathrm{HO}_{2}+\mathrm{NO}\right.$, red) and their ratios $($ black) during the BEACHON-ROCS field campaign.

the photolytic production term in the steady state equation which gives;

$$
\begin{aligned}
& \mathrm{R}(\mathrm{OH})=\mathrm{L}(\mathrm{OH})[\mathrm{OH}] \\
& {[\mathrm{OH}]=\mathrm{R}(\mathrm{OH}) / \mathrm{L}(\mathrm{OH})}
\end{aligned}
$$

where, $\mathrm{L}(\mathrm{OH})=\mathrm{OH}$ reactivity $\left(\mathrm{s}^{-1}\right), \mathrm{R}(\mathrm{OH})=\mathrm{OH}$ recycling rate $=\mathrm{k}_{\mathrm{HO}_{2}}+\mathrm{NO}\left[\mathrm{HO}_{2}\right][\mathrm{NO}]\left(\right.$ molecules $\left.\mathrm{cm}^{-3} \mathrm{~s}^{-1}\right)$

This simplified equation provides the important insight that uncertainties in $\mathrm{OH}$ reactivity and $\mathrm{OH}$ recycling rates directly affect the accuracy of estimates of $\mathrm{OH}$ concentration. Measured $\mathrm{OH}$ reactivity values in forest environments are significantly higher than expected from measured trace gases. The ratios of measured to calculated $\mathrm{OH}$ reactivity have been reported to range from 1 up to 10 (Lou et al., 2010; Sinha et al., 2010; Noelscher et al., 2012). Therefore, if the steady-state equation was constrained by trace gas measurements, instead of directly by $\mathrm{OH}$ reactivity measurements, then $[\mathrm{OH}]_{\mathrm{SS}}$ would have been overestimated by a factor of 1 to 10 . In addition, any uncertainty in the $\mathrm{OH}$ recycling rates linearly propagates to estimated $[\mathrm{OH}]_{\mathrm{ss}}$. These two independent sources of potential uncertainty can either cause an over- or underestimation of $[\mathrm{OH}]_{\mathrm{SS}}$ or result in reasonable predictions of ambient $\mathrm{OH}$ levels for the wrong reason. Only a comprehensive measurement suite can enable precise and accurate estimation of ambient $\mathrm{OH}$ concentrations. For example, a preliminary data analysis indicates that $\sim 50 \%$ of measured $\mathrm{OH}$ reactivity cannot be explained by the suite of VOC measurements (Nakashima et al., 2011). Therefore, the steady-state calculations without $\mathrm{OH}$ reactivity measurements would cause overestimation of $\mathrm{OH}$ by a factor of two.

\subsection{UWCM model calculations}

The predicted diurnal cycle in $\mathrm{OH}$ and $\mathrm{HO}_{2}$ using the UWCM model scheme $\left([\mathrm{OH}]_{\text {UWCM }}\right)$ is presented in Figs. 3 and 6 . In the base scenario (both $\mathrm{OH}$ and $\mathrm{HO}_{2}$ unconstrained), The UWCM significantly underestimates both $\mathrm{OH}$ and $\mathrm{HO}_{2}$ (by as much as a factor of 8) during the BEACHON-ROCS field campaign. Since the steady state analysis indicates that $\mathrm{HO}_{2}$ recycling is the main source for $\mathrm{OH}$ radicals, it is reasonable to hypothesize that the underprediction in $\mathrm{OH}$ is primarily due to the under-predicted $\mathrm{HO}_{2}$. Indeed, constraining the model with measured $\mathrm{HO}_{2}$ improves model-measurement agreement in the $\mathrm{OH}$ diurnal

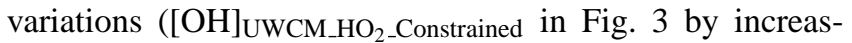
ing $\mathrm{OH}$ concentrations during the daytime up to a factor of 6. Conversely, if the model is constrained to measured $\mathrm{OH}$, modeled $\mathrm{HO}_{2}$ concentrations only increase by a factor of $\sim 2$ ([HO $\left.\mathrm{HO}_{2}\right]$ UwCM OH_Constrained in Fig. 6). As shown in Fig. 7, the model calculated $\mathrm{OH}$ reactivity in the difference constraining scenarios agrees with the observed values within $20 \%$. Therefore, the chemical lifetime of $\mathrm{OH}$ is well constrained in each applied model scenario considering significant variations in $\mathrm{OH}$ and $\mathrm{HO}_{2}$ levels in each model scenario. The reason for the higher predicted $\mathrm{OH}$ reactivity levels, when $\mathrm{HO}_{2}$ is constrained, probably results in excess formation of OVOCs due to the higher predicted OH levels (Fig. 3). 


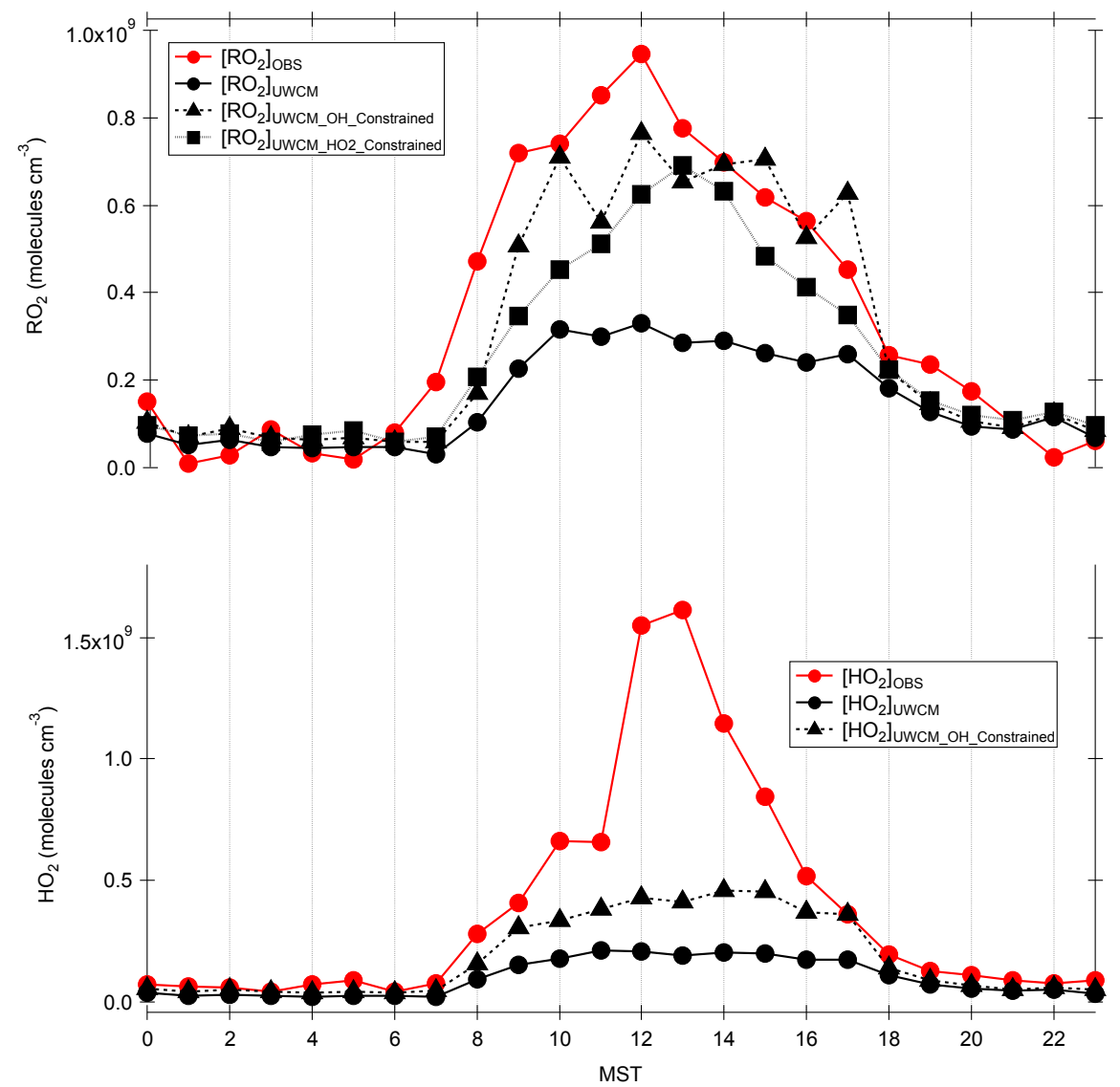

Fig. 6. The averaged diurnal cycles of $\left[\mathrm{HO}_{2}\right]_{\mathrm{MEA}},\left[\mathrm{HO}_{2}\right]_{\mathrm{UWCM}}$, and $\left[\mathrm{HO}_{2}\right]_{\text {UWCM_OH_Constrained }}$ in the bottom panel and $[\mathrm{RO}]_{\mathrm{MEA}}$, $\left[\mathrm{RO}_{2}\right]_{\text {UWCM }}$, and $\left[\mathrm{RO}_{2}\right]_{\text {UWCM_OH_Constrained }}$ during the BEACHON-ROCS field campaign.

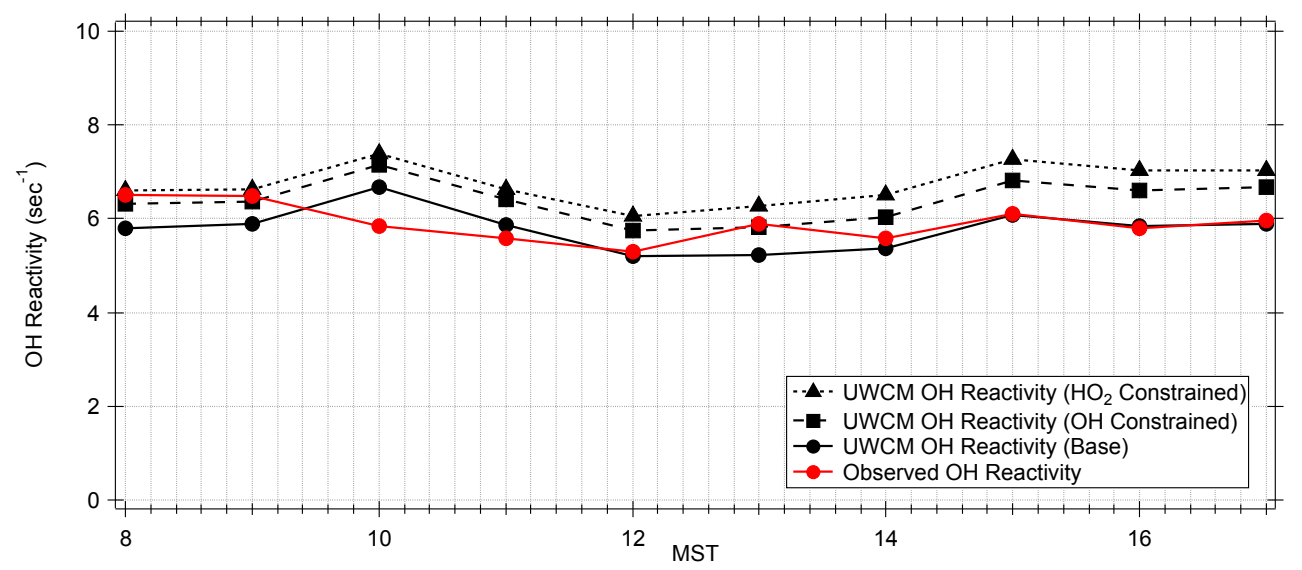

Fig. 7. The daytime variations of observed $\mathrm{OH}$ reactivity and UWCM calculated $\mathrm{OH}$ reactivity from the various model scenarios, described in the text.

Together, these results imply a source of $\mathrm{HO}_{2}$ that is not currently represented in the model. Our model results suggest a missing $\mathrm{HO}_{2}$ production rate of $1-7 \mathrm{ppbv} \mathrm{h}^{-1}$, which is $2-3$ times larger than total $\mathrm{HO}_{2}$ production from the known tropospheric photochemical processes as shown in Fig. 8. The figure shows specific $\mathrm{HO}_{2}$ chemical sources and sinks in the $\mathrm{HO}_{2}$ constrained UWCM calculations. The black solid line (L-P) in Fig. 8 indicates the required $\mathrm{HO}_{2}$ production rates to reconcile observed $\mathrm{HO}_{2}$ concentrations, which cannot be explained by the currently known sources of $\mathrm{HO}_{2}$. Potential 


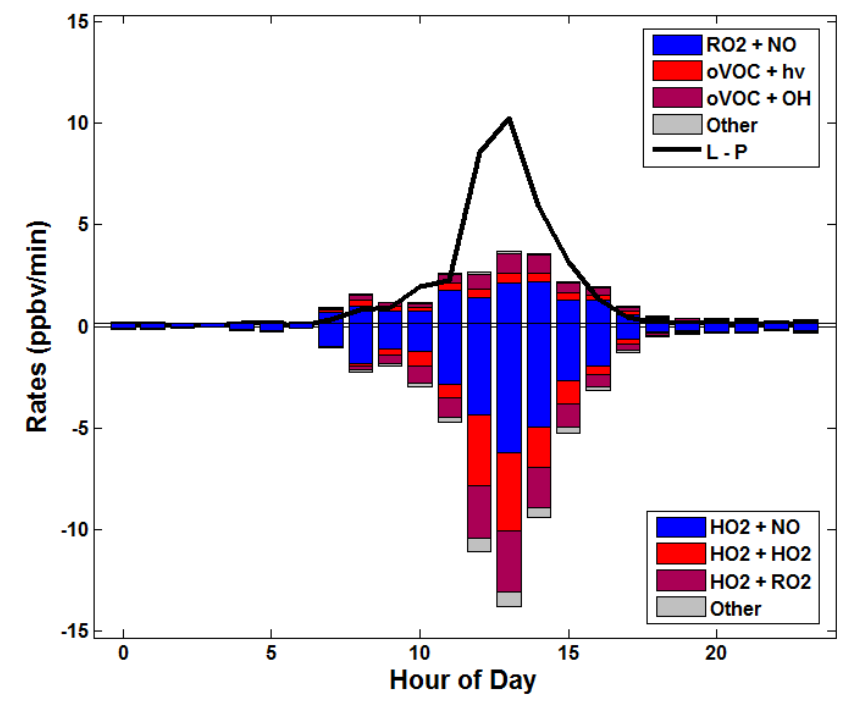

Fig. 8. UWCM model calculated $\mathrm{HO}_{2}$ loss and production rates in different photochemical pathways (indicated as the colored bars). The black solid line (overall loss rate - overall production rates; L-P) shows required production rates to resolve the observed unexplained higher $\mathrm{HO}_{2}$ level.

explanations for this missing source include (1) Transport of $\mathrm{HO}_{2}$ from more highly irradiated regions within or above the canopy, (2) photolysis of oxidized VOC or other species that are not included in the model, or (3) additional reactions of $\mathrm{RO}_{2}$ with unidentified reducing agents (e.g. Hofzumahaus et al., 2009). First, it is possible that the photolysis rates, scaled by the measured $J_{\mathrm{NO}_{2}}$ (Fig. 2), are not an accurate representation of the "average" canopy environment. This is a reasonable hypothesis, since the chemical lifetime of $\mathrm{HO}_{2}$ $(\sim 100 \mathrm{secs})$ is on the order of the timescale for canopy mixing/venting, so $\mathrm{HO}_{2}$ can be transported from sunny to shady areas under the forest canopy. Running the model under a full sun scenario (i.e. no photolysis attenuation) increases modeled $\mathrm{HO}_{2}$ concentrations by a factor of 2 - not enough to explain observed $\mathrm{HO}_{2}$ concentrations. If the entirety of the missing $\mathrm{HO}_{2}$ source is due to photolysis of unknown BVOCs, the $\mathrm{HO}_{2}$ production rate would need to be $\sim 100$ times that from HCHO photolysis. Given that the modeled $\mathrm{OH}$ reactivity is within $30 \%$ of observations (Nakashima et al., 2012), this seems unlikely. Still, it is possible that yetunidentified VOC degradation chemistry produces oxidized VOC that, by virtue of a short lifetime with respect to photolysis, do not build up to appreciable concentrations and thus do not contribute significantly to $\mathrm{OH}$ reactivity. Such compounds could also be directly emitted from the biosphere. This hypothesis would also be consistent with observations of anomalously high $\mathrm{HCHO}$ fluxes during the same campaign (DiGangi et al., 2011). Finally, modeled $\mathrm{HO}_{2}$ production stems primarily from reaction of $\mathrm{NO}$ with $\mathrm{RO}_{2}$ under the conditions of the current study, thus it might be possible to generate additional $\mathrm{HO}_{2}$ by augmenting this chem- istry. Indeed, modeled total peroxy radical concentrations $\left(\mathrm{RO}_{2}\right)$ agree moderately well with observations in the model run with $\mathrm{OH}$ constrained as shown in Fig. 6, suggesting issues in the partitioning of peroxy radicals. Implementing a scheme to convert $\mathrm{RO}_{2}$ to $\mathrm{HO}_{2}$ and $\mathrm{HO}_{2}$ to $\mathrm{OH}$ with an artificial reducing agent, as suggested by Hofzumahaus et al. (2009), effectively increases $\mathrm{OH}$ concentrations without affecting $\mathrm{HO}_{2}$. At present, however, we cannot account for the missing source of $\mathrm{HO}_{2}$. We are preparing a follow-up publication to specifically examine partitioning between $\mathrm{RO}_{2}$ and $\mathrm{HO}_{2}$ in a $\mathrm{MBO}$ dominant photochemical environment. It should be also noted that potential interferences in LIF techniques in $\mathrm{OH}$ quantifications from background quantification processes (Mao et al., 2012) and $\mathrm{HO}_{2}$ quantifications from $\mathrm{RO}_{2}$ radical (Fuchs et al., 2011). However, these reports on potential interferences have not been consistent from multiple studies. For example, a few recent studies about intercomparison between LIF techniques with DOAS and CIMS techniques reported excellent agreements between the techniques (Fuchs et al., 2012; Ren et al., 2011). One should also note that Hornbrook et al. (2011) indicated potential interferences in $\mathrm{HO}_{2}$ quantifications from $\mathrm{RO}_{2}$ from chemical conversion processes in the CIMS application for $\mathrm{HO}_{2}$ and $\mathrm{RO}_{2}$ quantifications.

These results suggest a need to rethink the oxidation capacity in the troposphere, especially in BVOC-dominated regions. As soon as an extremely short-lived species such as $\mathrm{OH}$ reacts with reactive BVOCs, it produces one or multiple $\mathrm{HO}_{\mathrm{x}}\left(\mathrm{OH}, \mathrm{HO}_{2}\right.$, or $\left.\mathrm{RO}_{2}\right)$. Therefore, the capacity of the oxidant pool $\left(\mathrm{HO}_{\mathrm{x}}\right)$ is maintained or even magnified through BVOC oxidation reactions. The oxidant pool, including $\mathrm{OH}, \mathrm{HO}_{2}$ and $\mathrm{RO}_{2}$, has a long enough lifetime $(\sim 100 \mathrm{~s})$ to be transported at the canopy scale (potentially even larger scales). The ratios of $\mathrm{OH}$ to $\mathrm{HO}_{2}$ are determined by the surrounding photochemical environment such as concentrations of NO or other potential reducing agents as hypothesized in recent publications (e.g. Hofzumahaus et al., 2009). This perspective is summarized in Fig. 9. The inability of an up-to-date near explicit chemical scheme to correctly reproduce the observed size of the oxidant pool propagates directly into estimates of oxidizing capacity inside of the canopy, which is mostly determined by $\mathrm{OH}$ concentrations. On the other hand, the present measurement dataset from MFO shows that constraining both the main component of the oxidant pool (mostly $\mathrm{HO}_{2}$ ) and oxidant-trace gas interaction ( $\mathrm{OH}$ reactivity) is sufficient to predict $\mathrm{OH}$ concentrations in this environment. Moreover, at MFO NO radical is sufficient to explain observed recycling rates. This finding strongly suggests that BVOCs other than isoprene, such as $\mathrm{MBO}$ and monoterpenes, do not cause an amplification of the oxidation capacity that have been reported in environments with high isoprene and comparable NO levels (Tan et al., 2001; Hofzumahaus et al., 2009; Lu et al., 2012). However, one should note that unknown $\mathrm{HO}_{2}$ sources are appeared to amplify oxidation capacity in this environment. 


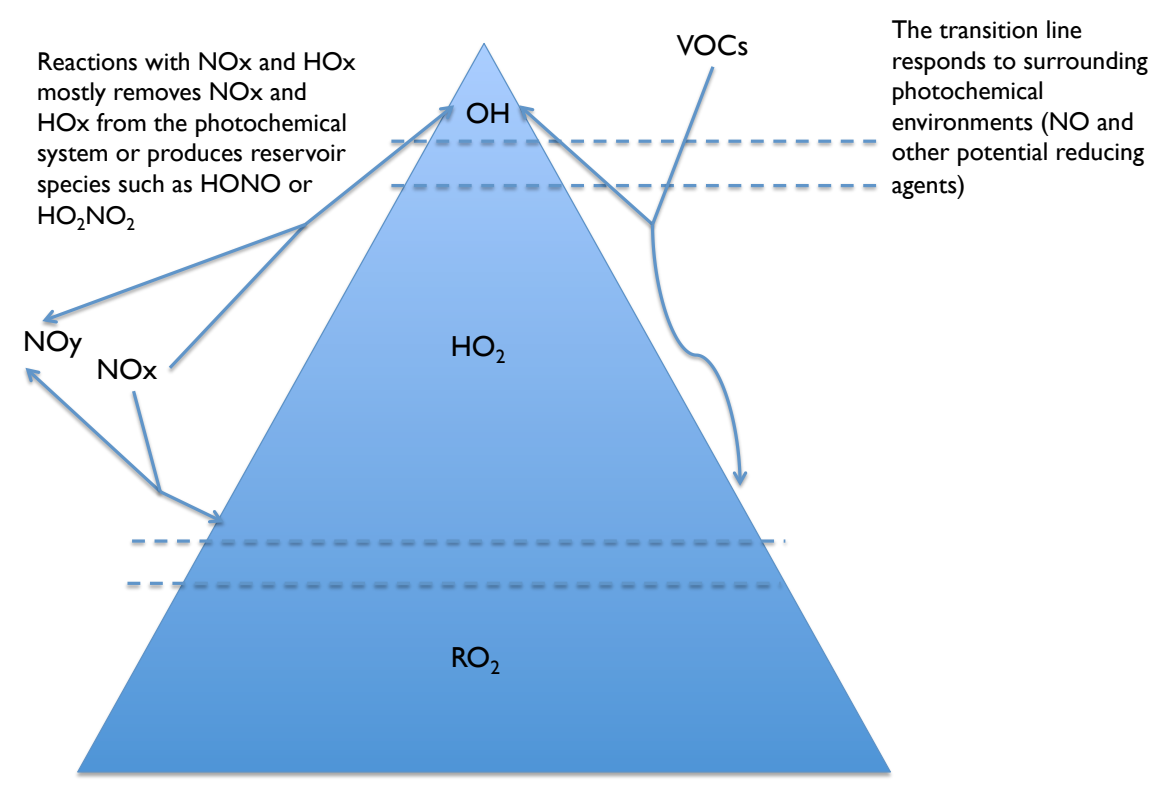

Fig. 9. Tropospheric interactions of oxidant pool $\mathrm{NO}_{\mathrm{x}}-\mathrm{NO}_{\mathrm{y}}-\mathrm{VOCs}\left(\mathrm{NO}_{\mathrm{y}}\right.$, reactive oxidized nitrogen). VOC oxidation by $\mathrm{OH}$ redistributes within the oxidant pool but does not change the size of the pool.

\section{Summary}

During the BEACHON-ROCS field campaign, a comprehensive measurement suite was deployed to constrain photolytic production, chemical loss and recycling of $\mathrm{OH}$. The results were used to evaluate our current understanding of $\mathrm{HO}_{\mathrm{x}}$ radical-BVOC (mostly, MBO and MT) interactions by comparing measured $\mathrm{OH}$ and model calculated $\mathrm{OH}$ using highly constrained steady-state $\left([\mathrm{OH}]_{\mathrm{SS}}\right)$ and explicit box model $\left([\mathrm{OH}]_{\text {UwCM }}\right)$ calculations. $[\mathrm{OH}]_{\text {SS }}$ shows an excellent agreement with $[\mathrm{OH}]_{\text {MEA }}$. Further analysis of photolysis production rates from ozone photolysis and recycling rates $\left(\mathrm{HO}_{2}+\mathrm{NO}\right)$ of $\mathrm{OH}$ indicate that the recycling production of $\mathrm{OH}$ is $\sim 20$ times higher than the photolysis production. Thus, in the canopy environment, $[\mathrm{OH}]_{\mathrm{SS}}$ is primarily controlled by the $\mathrm{HO}_{\mathrm{x}}$ recycling rate and total $\mathrm{OH}$ reactivity. Observational constraints on both $\mathrm{OH}$ sources and sinks provides a means to assess the magnitude of additional unknown $\mathrm{OH}$ production channels, which have been reported for isoprene-dominated environments with similar NO levels (Lu et al., 2012). Our results indicate that the conventional recycling pathway $\left(\mathrm{HO}_{2}+\mathrm{NO}\right)$ is dominant in a non-isoprene forest environment. In contrast, $[\mathrm{OH}]_{\text {UWCM }}$ shows very poor agreement with $[\mathrm{OH}]_{\text {MEA }}$. Once $\mathrm{HO}_{2}$ in the UWCM model calculations is constrained by $\left[\mathrm{HO}_{2}\right]_{\mathrm{MEA}},[\mathrm{OH}]_{\mathrm{UWCM}} \mathrm{HO}_{2}$-Constrained is in better agreement with $[\mathrm{OH}]_{\text {MEA }}$. Further model analysis suggests an unidentified source of $\mathrm{HO}_{2}$ that may be due to photolysis of oxidized VOC or reactions of $\mathrm{RO}_{2}$. Therefore, a simple box-model scheme may not accurately describe $\mathrm{HO}_{2}$ distributions inside of forest canopies and this uncertainty propagates directly into $\mathrm{OH}$ estimations. This discussion highlights the impor- tance of accurate measured constraints on the relatively longlived oxidant pool $\left(\mathrm{HO}_{2}\right.$ and $\left.\mathrm{RO}_{2}\right)$ and recycling processes such as reaction of $\mathrm{HO}_{2}$ with reducing agents (e.g. NO) and $\mathrm{HO}_{2}-\mathrm{RO}_{2}$ reaction mechanisms. Finally, as Atkinson (2000) claimed, more careful laboratory characterization of reaction kinetics of $\mathrm{RO}_{2}+\mathrm{NO}$ is required considering kinetic information about $\mathrm{RO}_{2}+\mathrm{NO}$ has been deduced from experiments with alkane originated proxy radicals.

Acknowledgements. The National Center for Atmospheric Research is operated by the University Corporation for Atmospheric Research under sponsorship from the US National Science Foundation. Any opinions, findings and conclusions or recommendations expressed in this publication are those of the authors and do not necessarily reflect the views of the National Science Foundation. The authors also thank the National Science Foundation (ATM 0852406) and the Austrian Science Fund (FWF): [L518]. Lisa Kaser is a recipient of a DOC-fFORTE-fellowship of the Austrian Academy of Sciences at the Institute of Ion Physics and Applied Physics. GMW acknowledges support from the NOAA Climate and Global Change Postdoctoral Fellowship Program. Finally, we thank the US Forest Service, specifically Richard Oakes, for logical support.

Edited by: R. Holzinger 


\section{References}

Alaghmand, M., Shepson, P. B., Starn, T. K., Jobson, B. T., Wallace, H. W., Carroll, M. A., Bertman, S. B., Lamb, B., Edburg, S. L., Zhou, X., Apel, E., Riemer, D., Stevens, P., and Keutsch, F.: The morning NOx maximum in the forest atmosphere boudary layer, Atmos. Chem. Phys. Discuss., 11, 2925129282, doi:10.5194/acpd-11-29251-2011, 2011.

Apel, E. C., Riemer, D. D., Hills, A., Baugh, W., Orlando, J., Faloona, I., Tan, D., Brune, W., Lamb, B., Westberg, H., Carroll, M. A., Thornberry, T., and Geron, C. D.: Measurement and interpretation of isoprene fluxes and isoprene, methacrolein, and methyl vinyl ketone mixing ratios at the PROPHET site during the 1998 intensive, J. Geophys. Res.-Atmos., 107, 4034 doi10.1029/2000jd000225, 2002.

Archibald, A. T., Jenkin, M. E., and Shallcross, D. E.: An isoprene mechanism intercomparison, Atmos. Environ., 44, 5356-5364, doi:10.1016/j.atmosenv.2009.09.016, 2010.

Atkinson, R.: Atmospheric chemistry of VOCs and $\mathrm{NO}_{\mathrm{x}}$, Atmos. Environ., 34, 2063-2100, 2000.

Carslaw, N., Creasey, D. J., Harrison, D., Heard, D. E., Hunter, M. C., Jacobs, P. J., Jenkin, M. E., Lee, J. D., Lewis, A. C., Pilling, M. J., Saunders, S. M., and Seakins, P. W.: $\mathrm{OH}$ and $\mathrm{HO}_{2}$ radical chemistry in a forested region of north-western Greece, Atmos. Environ., 35, 4725-4737, doi:10.1016/s1352-2310(01)00089-9, 2001.

Chameides, W. L. and Cicerone, R. J.: Effects of nonmethane hydrocarbons in atmosphere, J. Geophys. Res.-Ocean. Atmos., 83, 947-952, doi:10.1029/JC083iC02p00947, 1978.

Crounse, J. D., Paulot, F., Kjaergaard, H. G., and Wennberg, P. O.: Peroxy radical isomerization in the oxidation of isoprene, Phys. Chem. Chem. Phys., 13, 13607-13613, 2011.

Crutzen, P. J.: Photochemical reactions initiated by and influencing ozone in unpolluted tropospheric air, Tellus, 26, 47-57, 1974.

de Gouw, J. and Warneke, C.: Measurements of volatile organic compounds in the earths atmosphere using proton-transferreaction mass spectrometry, Mass Spectrom. Rev., 26, 223-257, 2007.

Di Gangi, J., Boyle, E. S., Karl, T., Turnipseed, A., Kim, S., Cantrell, C., Mauldin, R. L., Zheng, W., Flocke, F., Hall, S. R., Ullmann, K., Nakashima, Y., Paul, J. G., Wolfe, G. M., Desai, A. R., Kajii, Y., Guenther, A., and Keutsch, F.: First direct measurements of formaldehyde flux via eddy covariance: Implications for missing in-canopy formaldehyde sources, Atmos. Chem. Phys., 11, 10565-10578, doi:10.5194/acp-11-10565-2011, 2011.

DiGangi, J. P., Henry, S. B., Kammrath, A., Boyle, E. S., Kaser, L., Schnitzhofer, R., Graus, M., Turnipseed, A., Park, J.-H., Weber, R. J., Hornbrook, R., Cantrell, C., Maudlin, R. L., III, Kim, S., Nakashima, Y., Wolfe, G. M., Kajii, Y., Apel, E., Goldstein, A. H., Guenther, A., Karl, T., Hansel, A., and Keutsch, F. N.: Observations of glyoal and formaldehyde as metrics for the anthropogenic impact on rural photochemistry, Atmos. Chem. Phys., 12, 9529-5943, doi:10.5194/acp-12-9529-2012, 2012.

Edwards, G. D., Cantrell, C. A., Stephens, S., Hill, B., Goyea, O., Shetter, R. E., Mauldin, R. L., Kosciuch, E., Tanner, D. J., and Eisele, F. L.: Chemical ionization mass spectrometer instrument for the measurement of tropospheric $\mathrm{HO}_{2}$ and $\mathrm{RO}_{2}$, Analyt. Chem., 75, 5317-5327, 2003.

Eisele, F. L. and Tanner, D. J.: Ion-assisted tropospheric OH measurements, J. Geophys. Res.-Atmos., 96, 9295-9308, doi:10.1029/91jd00198, 1991.

Fuchs, H., Bohn, B., Hofzumahaus, A., Holland, F., Lu, K., Nehr, S., Rohrer, F., and Wahner, A.: Detection of $\mathrm{HO}_{2}$ by laser-induced fluorescence: Calibration and interferences from $\mathrm{RO}_{2}$ radicals, Atmos. Meas. Tech., 4, 1209-1225, doi:10.5194/amt-4-12092011, 2011.

Fuchs, H., Dorn, H.-P., Bachner, M., Bohn, B., Brauers, T., Gomm, S., Hofzumahaus, A., Holland, F., Nehr, S., Rohrer, F., Tillmann, R., and Wahner, A.: Comparison of oh concentration measurements by DOAS and LIF during SAPHIR chamber experiments at high $\mathrm{OH}$ reactivity and low NO concentrations, Atmos. Meas. Tech., 5, 1611-1626, doi:10.5194/amt-5-1611-2012, 2012.

Graus, M., Muller, M., and Hansel, A.: High resolution PTR-TOF: Quantification and formula confirmation of VOC in real time, J. Am. Soc. Mass Spectrom., 21, 1037-1044, 2010.

Heard, D. E. and Pilling, M. J.: Measurement of $\mathrm{OH}$ and $\mathrm{HO}_{2}$ in the troposphere, Chem. Rev., 103, 5163-5198, doi:10.1021/cr020522s, 2003.

Hofzumahaus, A., Rohrer, F., Lu, K. D., Bohn, B., Brauers, T., Chang, C. C., Fuchs, H., Holland, F., Kita, K., Kondo, Y., Li, X., Lou, S. R., Shao, M., Zeng, L. M., Wahner, A., and Zhang, Y. H.: Amplified trace gas removal in the troposphere, Science, 324, 1702-1704, doi:10.1126/science.1164566, 2009.

Hornbrook, R. S., Crawford, J., Edwards, G. D., Goyea, O., Mauldin, R. L., Olson, J. S., and Cantrell, C. A.: Measurements of tropospheric $\mathrm{HO}_{2}$ and $\mathrm{RO}_{2}$ by oxygen dilution modulation and chemical ionization mass spectrometry, Atmos. Meas. Tech., 4, 735-756, doi:10.5194/amt-4-735-2011, 2011.

Huisman, A. J., Hottle, J. R., Coenes, K. L., Di Gangi, J. P., Galloway, M. M., Kammrath, A., and Keutsch, F. N.: Laser-induced phosphorescence for the in situ detection of glyoxal at part per trillion mixing ratios, Analyt. Chem., 80, 5584-5591, 2008.

Jenkin, M. E., Saunders, S. M., and Pilling, M. J.: The tropospheric degradation of volatile organic compounds: A protocol for mechanism development, Atmos. Environ.. 31, 81-104, doi:10.1016/s1352-2310(96)00105-7, 1997.

Jenkin, M. E., Saunders, S. M., and Pilling, M. J.: The tropospheric degradation of volatile organic compounds: A protocol for mechanism development, Atmos. Environ., 31, 81-104, 1997.

Junkermann, F., Platt, U., and Volz-Thomas, A.: A photoelectric detector for the measurement of photolysis frequencies of ozone and other atmospheric molecules, J. Atmos. Chem., 8, 203-227, 1989.

Kaser, L., Karl, T., Schnitzhofer, R., Graus, M., Herdlinger-Blatt, I. S., DiGangi, J. P., Sive, B., Turnipseed, A., Hornbrook, R. S., Zheng, W., Flocke, F. M., Guenther, A., Keutsch, F. N., Apel, E., and Hansel, A.: Comparison of different real time VOC measurement techniques in a ponderosa pine forest, Atmos. Chem. Phys. Discuss., 12, 27955-27988, doi:10.5194/acpd-12-279552012, 2012.

Kim, S., Karl, T., Guenther, A., Tyndall, G., Orlando, J., Harley, P., Rasmussen, R., and Apel, E.: Emissions and ambient distributions of biogenic volatile organic compounds (BVOCs) in a ponderosa pine ecosystem: Interpretation of PTR-MS mass spectra, Atmos. Chem. Phys., 10, 1759-1771, doi:10.5194/acp-10-17592010, 2010.

Lelieveld, J., Butler, T. M., Crowley, J. N., Dillon, T. J., Fischer, H., Ganzeveld, L., Harder, H., Lawrence, M. G., Martinez, M., Taraborrelli, D., and Williams, J.: Atmospheric oxidation 
capacity sustained by a tropical forest, Nature, 452, 737-740, doi:10.1038/nature06870, 2008.

Levy, H.: Normal atmosphere - large radical and formaldehyde concentrations predicted, Science, 173, 141-143, doi:10.1126/science.173.3992.141, 1971.

Levy, H.: Photochemistry of lower troposphere, Planet Space Sci., 20, 919-935, doi:10.1016/0032-0633(72)90177-8, 1972.

Logan, J. A., Prather, M. J., Wofsy, S. C., and McElroy, M. B.: Tropospheric chemistry - a global perspective, J. Geophys. Res.Ocean. Atmos., 86, 7210-7254, doi:10.1029/JC086iC08p07210, 1981.

Lou, S., Holland, F., Rohrer, F., Lu, K., Bohn, B., Brauers, T., Chang, C. C., Fuchs, H., Haseler, R., Kita, K., Kondo, Y., Li, X., Shao, M., Zeng, L., Wahner, A., Zhang, Y., Wang, W., and Hofzumahaus, A.: Atmospheric $\mathrm{OH}$ reactivities in the Pearl River Delta - China in summer 2006: Measurement and model results, Atmos. Chem. Phys., 10, 11243-11260, doi:10.5194/acp-10-11243-2010, 2010.

Lovelock, J. E.: Methyl chloroform in troposphere as an indicator of $\mathrm{OH}$ radical abundance, Nature, 267, 32-32, doi:10.1038/267032a0, 1977.

Lu, K. D., Rohrer, F., Holland, F., Fuchs, H., Bohn, B., Brauers, T., Chang, C. C., Haseler, R., Hu, M., Kita, K., Kondo, Y., Li, X., Lou, S. R., Nehr, S., Shao, M., Zeng, L. M., Wahner, A., Zhang, Y. H., and Hofzumahaus, A.: Observation and modelling of $\mathrm{OH}$ and $\mathrm{HO}_{2}$ concentrations in the Pearl River Delta 2006: A missing oh source in a voc rich atmosphere, Atmos. Chem. Phys., 12, 1541-1569, doi:10.5194/acp-12-1541-2012, 2012.

Mao, J., Ren, X., Zhang, L., Van Duin, D. M., Cohen, R. C., Park, J.-H., Goldstein, A. H., Paulot, F., Beaver, M. R., Crounse, J. D., Wennberg, P. O., DiGangi, J. P., Henry, S. B., Keutsch, F. N., Park, C., Schade, G. W., Wolfe, G. M., Thornton, J. A., and Brune, W. H.: Insights into hydroxyl measurements and atmospheric oxidation in a california forest, Atmos. Chem. Phys., 12, 8009-8020, doi:10.5194/acp-12-8009-2012, 2012.

Mauldin, R. L., Berndt, T., Sipila, M., Paasonen, P., Petaja, T., Kim, S., Kurten, T., Stratmann, F., Kerminen, V. M., and Kulmala, M.: A new atmospherically relevant oxidant of sulphur dioxide, Nature, 488, 193-196, doi:10.1038/nature11278, 2012.

Mauldin, R. L., Kosciuch, E., Eisele, F. L., Huey, L. G., Tanner, D. J., Sjostedt, S. J., Blake, D., Chen, G., Crawford, J., and Davis, D.: South pole Antarctica observations and modeling results:New insights on $\mathrm{HO}_{\mathrm{x}}$ radical and sulfur chemistry, Atmos. Environ., 44, 572-581, 2010.

Nakashima, Y., Ida, A., Kajii, Y., Greenberg, J., Karl, T., Kim, S., Turnipseed, A., Guenther, A., Di Ganigi, J., Henry, J., Keutsch, F., Schnitzhofer, R., Kaser, L., and Hansel, A.: Total OH reactivity measurements at manitou experimental forest in summer season during beachon-rocs field campaign, American Geophysical Union Fall Meeting, San Francisco, CA USA, 2011.

Nakashima, Y., Ida, A., Kajii, Y. J., Greenberg, J., Karl, T., Kim, S., Turnipseed, A., Guenther, A. B., DiGangi, J. P., Henry, S. B., Keutsch, F. N., Schnitzhofer, R., Kaser, L., and Hansel, A.: Total $\mathrm{OH}$ reactivity measurements at the Manitou Experimental Forest in summer season during BEACHON-ROCS campaign, Atmos. Chem. Phys., in preparation, 2013.

Nolscher, A. C., Williams, J., Sinha, V., Custer, T., Song, W., Johnson, A. M., Axinte, R., Bozem, H., Fischer, H., Pouvesle, N., Phillips, G., Crowley, J. N., Rantala, P., Rinne, J., Kulmala, M.,
Gonzales, D., Valverde-Canossa, J., Vogel, A., Hoffmann, T., Ouwesloot, H. G., Vila-Guerau de Arellano, J., and Lelieveld, J.: Summertime total oh reactivity measurements from boreal forst during HUMPPA-COPEC 2010, Atmos. Chem. Phys., 12, 8257 8270, doi:10.5194/acp-12-8257-2012, 2012.

Peeters, J. and Müller, J. F.: $\mathrm{HO}_{\mathrm{x}}$ radical regeneration in isoprene oxidation via peroxy radical isomerisations. II: experimental evidence and global impact, Phys. Chem. Chem. Phys., 12, 1422714235,2010

Peeters, J., Nguyen, T. L., and Vereecken, L.: $\mathrm{HO}_{\mathrm{x}}$ radical regeneration in the oxidation of isoprene, Phys. Chem. Chem. Phys., 11, 5935-5939, 2009.

Petaja, T., Mauldin, R. L., Kosciuch, E., McGrath, J., Nieminen, T., Paasonen, P., Boy, M., Adamov, A., Kotiaho, T., and Kulmala, M.: Sulfuric acid and $\mathrm{OH}$ concentrations in a boreal forest site, Atmos. Chem. Phys., 9, 7435-7448, doi:10.5194/acp-97435-2009, 2009.

Ren, X., Mao, J., Brune, W., Cantrell, C., Maudlin, R. L., Hornbrook, R., Kosciuch, E., Olson, J. R., Crawford, J., Chen, G., and Singh, H. B.: Airbonre intercomparison of $\mathrm{HO}_{\mathrm{x}}$ measurements using laser-induced fuorescence and chemical ionization mass spectrometer during ARCTAS, Atmos. Meas. Tech., 5, 20252037, doi:10.5194/gmd-5-2025-2012, 2012

Sadanaga, Y., Yoshino, A., Watanabe, K., Yoshioka, A., Wakazono, Y., Kanaya, Y., and Kajii, Y.: Development of a measurement system of $\mathrm{OH}$ reactivity in the atmosphere by using a laserinduced pump and probe tehenqiue, Rev. Sci. Instr., 75, 26482655, 2004.

Saunders, S. M., Jenkin, M. E., Derwent, R. G., and Pilling, M J.: Protocol for the development of the Master Chemical Mechanism, MCM v3 (Part A): tropospheric degradation of nonaromatic volatile organic compounds, Atmos. Chem. Phys., 3, 161-180, doi:10.5194/acp-3-161-2003, 2003.

Sinha, V., Williams, J., Lelieveld, J., Ruuskanen, T. M., Kajos, M. J., Patokoski, J., Helllen, H., Hakola, H., Mogensen, D., Boy, M., Rinne, J., and Kulmala, M.: OH reactivity measurements within a Boreal Forest: Evidence for unknown reactive emissions, Environ. Sci. Technol., 44, 6614-6620, 2010.

Singh, H. B.: Atmospheric halocarbons - evidence in favor of reduced average hydroxyl radical concentration in troposphere, Geophys. Res. Lett., 4, 101-104, doi:10.1029/GL004i003p00101, 1977.

Sjostedt, S. J.: Investigation of photochemistry at high latitudes: Comparison of model predictions to measurements of short lived species, Ph. D., Earth and Atmospheric Sciences, Georgia Institute of Technology, Atlanta, USA, 174 pp., 2006

Slusher, D. L., Huey, L. G., Tanner, D. J., Flocke, F., and Roberts, J. M.: A thermal dissociation-chemical ionization mass spectrometry (TD-CIMS) technique for the simultaneous measurement of peroxyacyl nitrates and dinitrogen pentoxide, J. Geophys. Res., 109, D19315, doi:10.1029/2004JD004670, 2004.

Stavrakou, T., Peeters, J., and Müller, J.-F.: Improved global modelling of $\mathrm{HO}_{\mathrm{x}}$ recycling in isoprene oxidation: evaluation against the GABRIEL and INTEX-A aircraft campaign measurements, Atmos. Chem. Phys., 10, 9863-9878, doi:10.5194/acp-10-98632010, 2010.

Tan, D., Faloona, I., Simpas, J. B., Brune, W., Shepson, P. B., Couch, T. L., Sumner, A. L., Carroll, M. A., Thornberry, T., Apel, E., Riemer, D., and Stockwell, W.: $\mathrm{HO}_{\mathrm{x}}$ budgets 
in a deciduous forest: Results from the PROPHET summer 1998 campaign, J. Geophys. Res.-Atmos., 106, 24407-24427, doi:10.1029/2001jd900016, 2001.

Tanner, D. J., Jefferson, A., and Eisele, F. L.: Selected ion chemical ionization mass spectrometric measurement of $\mathrm{OH}, \mathrm{J}$. Geophys. Res.-Atmos., 102, 6415-6425, doi:10.1029/96jd03919, 1997.

Whalley, L. K., Edwards, P. M., Furneaux, K. L., Goddard, A., Ingham, T., Evans, M. J., Stone, D., Hopkins, J. R., Jones, C. E., Karunaharan, A., Lee, J. D., Lewis, A. C., Monks, P. S., Moller, S. J., and Heard, D. E.: Quantifying the magnitude of a missing hydroxyl radical source in a tropical rainforest, Atmos. Chem. Phys., 11, 7223-7233, doi:10.5194/acp-11-7223-2011, 2011.
Wofsy, S. C., McConnel, J. C., and McElroy, M. B.: Atmospheric $\mathrm{CH}_{4}, \mathrm{CO}$, and $\mathrm{CO}_{2}$, J. Geophys. Res., 77, 4477-4493, doi:10.1029/JC077i024p04477, 1972.

Wolfe, G. M. and Thornton, J. A.: The Chemistry of AtmosphereForest Exchange (CAFE) Model - Part 1: Model description and characterization, Atmos. Chem. Phys., 11, 77-101, doi:10.5194/acp-11-77-2011, 2011.

Wolfe, G. M., Crounse, J. D., Parrish, J. D., St. Clair, J. M., Beaver, M. R., Paulot, F., Yoon, T. P., Wennberg, P. O., and Keutsch, F. N.: Photolysis, OH reactivity and ozone reactivity of a proxy for isoprene-derived hydroperoxyenals (HPALDs), Phys. Chem. Chem. Phys., 14, 7276-7286, doi:10.1039/C2CP40388A, 2012. 